\title{
Transformational Islamic Education Ideas: Abdurrahman Wahid's Perspective
}

\author{
Samsudin 1 , Widiati Isana ${ }^{2}$, Yasmin Astri ${ }^{3}$
}

DOI: $10.35445 /$ alishlah.v13i3.848

Article Info

Keywords:

Islamic Education;

Transformative;

Abdurrahman Wahid

Kata kunci:

Pendidikan Islam;

Transformatif;

Abdurrahman Wahid

\section{Abstract}

This article examines Abdurrahman Wahid's (often referred to as Gus Dur) views on transformative Islamic education. This is a qualitative study conducted in a library. This research compiled a collection of Gus Dur's writings on transformative Islamic education. The data collection technique used in this study was content analysis. In comparison, the authors used procedures for compiling, connecting, reducing, presenting, and withdrawing data during the data analysis process. According to Abdurrahman Wahid's thinking, this study discovered two concepts of transformative Islamic education: peace education and multicultural education. In informal education, Gus Dur's idea of peace education can be implemented through a sociopolitical lens through cooperative learning strategies. In contrast, in non-formal education, it can be implemented through dialogue and deliberation strategies. Multicultural education is Gus Dur's vision of education to foster heterogeneity in Indonesian society. Because, as Gus Dur points out, Indonesia is made up of numerous ethnic groups, tribes, cultures, and religions. As a result, the Indonesian people face the possibility of conflict over religion, ethnicity, and culture.

\begin{abstract}
Abstrak
Tulisan ini mengkaji tentang pemikiran Abdurrahman Wahid atau yang sering disapa dengan nama Gus Dur tentang pendidikan islam transformatif. Penelitian ini merupakan penelitian kepustakaan library research dengan menggunakan metode kualitatif. Penelitian ini dilakukan dengan cara mengumpulkan pelbagai tulisan tentang Gus Dur mengenai pendidikan Islam transformatif. Teknik pengumpulan data pada penelitian ini dilakukan dengan metode content analisys, sedangkan dalam proses analisis data, penulis menggunakan prosedur menyusun data, menghubungkan data, mereduksi data, penyajian data, dan penarikan data. Penelitian ini menemukan bahwa terdapat dua gagasan pendidikan Islam transformatif menurut pemikiran Abdurrahman Wahid, yaitu pendidikan perdamaian dan pendidikan multikultural. Dalam pendidikan formal, gagasan pendidikan perdamaian Gus Dur dapat diimplementaskan melalui pendekatan sosial-politik dengan memperaktekkan strategi pembelajaran cooperatif learning, sedangkan dalam pendidikan non-formal dapat diimplementasikan melalui strategi dialog dan musyawarah. Pendidikan multikultural merupakan gagasan pendidikan perspektif Gus Dur untuk melahirkan sifat heterogenitas dalam diri masyarakat Indonesia. Karena menurut Gus Dur Indonesia memiliki berbagai macam etnis, suku, budaya, dan agama. Sehingga masyarakat Indonesia sangat berpotensi mengalami konflik yang mengatasnamakan agama, etnis, dan budaya.
\end{abstract}

\footnotetext{
${ }^{1}$ Universitas Islam Negeri Gunung Djati Bandung

Email: samsudin@uinsgd.ac.id

2Universitas Islam Negeri Sunan Gunung Djati Bandung

Email: widiatiisana@uinsgd.ac.id

3Universitas Islam Negeri Sunan Gunung Djati Bandung

Email: wikanastri87@gmail.com
} 


\section{INTRODUCTION}

Abdurrahman Wahid or Gus Dur is one of the inspirations for Islamic reform in Indonesia. $\mathrm{He}$ is a figure who has developed many transformative ideas like his opinion that the goals in Islamic education must be related to morality and the improvement of the fate of many people. And for the welfare of the people. Such thoughts and efforts are often carried out by people whose religion is lacking (Wahid, 2006, p. 72). At the same time, Islam is a transformative religion that always defends the people.

This paper examines the thoughts of Abdurrahman Wahid or who is often called by name Gus Dur, about transformative Islamic education. According to the author, by implementing Gus Dur's educational ideas, Islamic education will undergo a transformation, namely changing the condition of the weak into the firm, backward to advancing, uncivilized into civilized, and ultimately always wanting to change the situation towards a better life (Echols \& Shadly, 1987, p. 601).

In order to avoid overlapping research, the author conducted a literature review of previous research that discussed Gus Dur's thoughts and Islamic education. The literature review results that the author did include the following: First, the research conducted by Mulyadi with the title Gus Dur's Thoughts on Multicultural Islamic Education (Mulyadi, 2019). Second, M. Ma'ruf's research entitled Typology of Gus Dur's Thought on Islamic Education (Ma'ruf, 2020). Third, Halimatus Sa'diyah and Sri Nurhayati on Gus Dur's Perspective of Peace Education: A Philosophical Study of Gus Dur's Educational Thought (Sa'diyah \& Nurhayati, 2019). Fourth, Miskan's research entitled Multiculturalism Thought KH. Abdurrahman Wahid and its Implications for Islamic Religious Education in Indonesia (Miskan, 2018). Fifth, Deden Saiful Ridhwan's research entitled Essence of Islamic Education in the Perspective of KH. Abdurrahman Wahid (Ridhwan, 2018).

Based on the results of the literature review that has been done, the authors did not find any research that specifically examined the idea of transformative Islamic education from the perspective of Gus Dur's thought. Therefore, this research is very relevant to realize Islamic education in Indonesia, which is weak into strong, backward becomes forward, uncivilized becomes civilized, and ultimately always wants to change the situation towards a better life.

\section{METHOD}

This research is library research (Usman, 2006) using qualitative methods (Kasmahidayat, 2010). This research collected various writings about Gus Dur on transformative Islamic education. The data collection technique in this study was carried out using the content analysis method, namely analyzing Abdurahman Wahid's writings considered related to the research theme (Sutrisno, 1998). Meanwhile, in data analysis, the author uses the following procedures: compiling data, connecting data, reducing data, presenting data, and withdrawing data (Salim \& Sahrum, 2007).

\section{FINDINGS AND DISCUSSION}

\section{Gus Dur: Transformative Islamic Leader}

Abdurrahman Wahid, who we often know by the name of Gusdur, is the grandson of Nahdhatul Ulama Hadrotus Sheikh Hasyim Asy'ari, and the son of one of the national heroes KH. Wahid Hashim. The father of Pluralism and the "Warrior of Humanity" was born in Jombang, 7 September 1940. When his father was appointed as Minister of Religion, small Gus Dur moved to Jakarta in 1949. There he was taught by his father to read magazines, non-Muslim books. Muslims, literary works, and newspapers to expand Gus Dur's knowledge.

However, then tragedy struck in April 1953 KH. Wahid Hasyim, Gus Dur's father, died in a car accident. After that, Gus Dur continued to Junior High School, but he did not go up a grade in 
that year. His mother then sent Gus Dur to Yogyakarta to continue his education at KH. Ali Maksum at the Krapyak Islamic Boarding School. After completing his junior high studies in Yogyakarta, then Gus Dur continued his studies at the Islamic Boarding School in Magelang. There, he was able to complete the study period that should have been four years, which became two years. He moved again to the Tambakberas Islamic Boarding School, Jombang, where he became a teacher and later became a madrasa principal while working as a journalist at Horizon and Culture Jaya Magazine (Wahid, 2017).

In 1963, Gus Dur continued his studies at Cairo's Al-Azhar University, thousands of years old and much older than the best European campuses such as Oxford in England, Cambridge, and the Sorbonne. Although Gus Dur was initially excited to study at the oldest campus, not long ago, Gus Dur felt disappointed with the educational methods and materials he had mastered since he was at the Islamic boarding school. Finally, he moved to Iraq and received a scholarship at the University of Baghdad. After graduating from Iraq, Gus Dur travelled to the Netherlands to study at Leiden University (Barton, 2016). Besides studying at Leiden, Gusdur also wants to continue his studies at McGill University, Canada. Gus Dur joined the Institute for Economic and Social Research, Education and Information (LP3ES) to support this. However, with his always loving nature, Gus Dur never discriminated against someone from their background. Gus Dur did not look at humans through the lens of religion, politics, ethnicity, parties, mass organizations, and other attributes. Gus Dur's focus was on humans and humanity itself (Husein, 2021).

With his busy life joining the ordinary people, Gus Dur also lived a life selling peanuts and ice travelling around in 1974, and then he was appointed general secretary of the Tebuireng pesantren until 1980. In 1984 Gus Dur was entrusted with the mandate to become chairman of the PBNU tanfizh board. Furthermore, in 1989 Gus Dur became a member of the People's Consultative Assembly of the Republic of Indonesia. Moreover, at the end of his career, he was sworn in as President of the Republic of Indonesia in 1999, even though he only served for 20 months. Apart from being busy with taking care of the country and the people, it does not mean that he does not have written works. As for Gusdur's works, Kiai Nyetrik membela pemerintah (1987), Kontroversi Pemikiran Islam di Indonsia (1990), Politik Demi Tuhan : Nasionalisme Religius Di Indonesia (1999), Mengurai Hubungan Agama dan Negara (1999), Melawan Melalui Lelucon (2000 ), Pergulatan Negara, Agama, dan Kebudayaan (2001), Islamku, Islam Anda, Islam Kita (2006) and others (Wahid, 2017).

Gus Dur's example in respecting other people is reflected in his defence of the Kong-HuChu people. Where at that time, the adherents of Kong-Hu-Chu were still discriminated against in Indonesia. Gus Dur inaugurated them as a nationally recognized religion. Another tolerant attitude of Gus Dur's figure can also be seen in how he treated people who used to be his political rivals.

Although he has been hated and hurt by people several times because of his often controversial decisions, Gus Dur still loves those who have hurt him. Because only with love, tolerance, and peace between fellow human beings. Gus Dur has always consistently carried the spirit of working for humanity, divinity, and peace throughout his life. Because of his struggle, Gus Dur has won several international class awards in various fields. No less than 7 Honoris Causa Doctorate degrees were given to Gus Dur, including; Honorary Doctorate of Soka Gakkai University (Tokyo, Japan), Honorary Doctor of Humanities from Netanya University (Israel), Honorary Doctor of Law from Konkuk University (Seoul, South Korea), Honorary Doctor of Humanities from Sorbonne University (Paris) However, the series of achievements that he made did not make Gus Dur proud and live a happy life. Gus Dur was still the tolerant Gus Dur. Gus Dur remains a role model for his lifestyle, house, and living room which is still straightforward and still simple. Continue to be a loyal role model to comfort the hearts of marginalized and marginalized people-Istiqamah in defending people who are weakened and excluded. 


\section{Basic Concepts of Islamic Education}

Education is an essential element in realizing the welfare of society because education has a role in determining attitudes, behaviour, and human character as the meaning of education as outlined by Nurkholis in his journal that education is a processing process to change the psyche, to mature one's feelings, thoughts, sincerity, and personality (Nurkholis, 2013).

The basics of Islamic education are principally laid on the foundations of Islamic teachings and all of its cultural apparatus (Ghazali \& Busro, 2017). The first and foremost foundations for the formation and development of Islamic education are the Qur'an and Al-Hadith. The basis of further Islamic education is social values that do not conflict with the Qur'an and Al-Hadith on the principle of bringing a benefit and keeping it away from harm. Then the legacy of the thoughts of Muslim scholars and scholars is an essential basis in Islamic religious education (Azra, 1999; Busro, Mailana, \& Sarifudin, 2021).

According to Bukhari Umar in his book Science of Islamic Education, there are three meanings of education in Islam, while the three meanings are as follows: First, education means ta'lim, namely, masdar from the word 'allama, which means teaching that is giving or conveying understanding, knowledge, and understanding. Skills. Second, Ta'bid is an educational process that is more focused on fostering and perfecting the character or character of students. Third, Tarbiyah, is a masdar from the word rabba, which means to nurture, educate and nurture (Bukhari, 2010). Then according to Asep Ahmad Sukandar in his book Thought on Islamic Education, he defines education as riyadhah, namely education that is oriented more towards the education of the child's soul to the noble character (Hori, 2020).

\section{Transformative Islamic Education: Gus Dur's Perspective}

The basics of Islamic education are principally laid on the foundations of Islamic teachings and all of its cultural apparatus. The first and foremost foundations for the formation and development of Islamic education are the Qur'an and Al-Hadith. The basis of further Islamic education is social values that do not conflict with the Qur'an and Al-Hadith on the principle of bringing a benefit and keeping it away from harm. Then the legacy of the thoughts of Muslim scholars and scholars is an essential basis in Islamic religious education.

Transformative or what in English is called transformation means changing shape, being, and moving. So that transformative Islamic education can be interpreted as an Islamic education system that wants to change the education culture from backwards to the advanced education system, from uncivilized education to civilized one (Echols and Shadly: 1987: 601: Nata, 2001: 78).

Abdurrahman Wahid or Gus Dur is one of the inspirations for Islamic reform in Indonesia. $\mathrm{He}$ is a figure who has developed many transformative ideas like his opinion that the goals in Islamic education must be related to morality and the improvement of the fate of many people And for the welfare of the people. Such thoughts and efforts are often carried out by people whose religion is lacking (Rachman, 2006, pp. 131, 135). At the same time, Islam is a transformative religion that always defends the people.

Since childhood, this idea has aspired, which expects a gradual social transformation towards an open, modern society with solid individual rights. This opinion was conveyed when he was interviewed by Panji Masyarakat magazine in 1984 (Wahid, 1984). Then according to him, he must be able to distinguish the teachings of Islam and the interests of Muslims. What must be done is first to mature the cultural insight of Muslims by opening up as much as possible to dialogue with other parties and trying to understand as far as possible the aspirations that live among the people. Second, it is necessary to mature the inner life of Muslims by dealing with their interests from various points of view. Third, start by developing a democratic political culture-fifth, pioneering socio-economic institutions with a collective character at the lower levels. Sixth, filling the education chain that fosters people who have the spirit of educators. Seventh, forming modern communication with traditional people. The Indonesian people must make these seven efforts to 
change their fate critically rather than always discussing the state or Islamic law (Wahid, 1983, $\mathrm{p}$. 53).

In addition, in this paper, the author will explain two important ideas of Gus Dur about transformative Islamic education as academic insights to create effective Islamic education in Indonesia. The two educational ideas are peace education and multicultural education.

\section{Gus Dur Peace Education}

The peace education that Gus Dur gave birth to cannot be separated from his figure, who always loves and respects fellow human beings. According to Husein Muhammad, Gus Dur is a person who always wants his life to be entirely devoted to humans and humanity through various mechanisms, including upholding human rights, pluralism, democracy, and the peak is love (Husein, 2021). Just as God loves His creatures, Gus Dur also wants to love them. Gus Dur did not talk much about the pluralism discourse and its theological arguments. But he practiced, and set an example for it (Husein, 2021). That is why many people from various religions loved Gus Dur, even when he died, not only Muslims who mourned, but all religious circles. Gus Dur often said that Islam consisted of 3 pillars: the Pillars of Faith, the Pillars of Islam, and the Pillars of Neighbors. Gus Dur wanted to remind Muslims that one of the goals of religion is human life in the world. For this, Gus Dur often talks about honesty, sincerity in work, determination, patience in fighting, respecting people, and advocating for those who suffer and are oppressed. More than that, he not only appreciates or respects humans who do good but also welcomes them with humility and a warm embrace (Husein, 2021).

For Gus Dur, all human beings are the same, no matter where they come from, what gender they are, their skin colour, ethnicity, race, and nationality. What Gus Dur saw was that they were human-like himself and the others. what he saw was his good intentions and deeds, as the Prophet said; "God does not look at your body and face, but your behaviour and heart (Husein, 2021)." Gus Dur embodied Islamic values in the form of concern regarding human aspects. Re-spread the image that Islam is a religion that is rahmatan Lil 'Alamin. Furthermore, it emphasized that Islam is a religion that focuses on the individual and a collectivity in society supported by an attitude of tolerance and mutual respect.

Service to humanity is not just a matter of morality alone, but more than that if it is associated with religious awareness, service to humanity is one proof of devotion to God in its social manifestations. A characteristic is that a person is not only concerned with his profit (egocentric). According to one of the Sufis, Abi Sa'id bin Abi al-Khair, "There is no shortest, best and fastest way to Him other than giving comfort to others (Husein, 2021)."

In the formal Islamic education system, such as; In schools, madrasas, and Islamic boarding schools, Gus Dur's peace education can be implemented through a socio-political approach by practicing cooperative learning strategies (Wahid, 1999).

A cooperative learning strategy is a learning strategy that develops mutual respect between each other, which aims to avoid misunderstandings or offences between students, leading to hostility. Cooperative learning strategies can also help students work together in solving learning and social problems that occur in school and community life (Triani, 2016).

While in non-formal education, such as; the activities of ta'lim assemblies, tarekat forums, recitations, and so on, as well as in social life, Gus Dur's model of peace education can be pursued through dialogue and deliberation strategies. Because prioritizing the concept of dialogue and community deliberation will avoid the nature of violence and build humanity (Dharwis, 1998). 


\section{Multicultural education according to Gusdur}

According to Gus Dur, multicultural education is a way to create heterogeneity in Indonesian society (Miskan, 2018). Gus Dur's opinion was based on the fact that Indonesia has various ethnicities, tribes, cultures, and religions. So it is very potential for acts of terrorism in the name of religion. Like the case of the bombing of several churches in Surabaya, including; The Immaculate Santa Maria Church, the Indonesian Christian Church on Jalan Diponegoro, and the Pentecostal Church on Jalan Arjuno (Halim \& Adnan, 2018). In addition, there are many acts of terrorism based on religious understanding, such as the 2002 Bali Bombings, 2005 Bali Bombings, the $2003 \mathrm{JW}$ Mariott Hotel bombings, the 2016 Sarinah bombings, the 2017 Jakarta Kampung Melayu bombings, and so on (Nurani \& Nurdin, 2018).

The occurrence of these cases is due to extreme views in religious attitudes so that in order to obtain the degree of "martyrdom," they are willing to kill fellow human beings. At the same time, the essence of religious teachings is to maintain safety and maintain peace (Handoko, 2019). Therefore, multicultural education is very effective and efficient in giving birth to the nature of openness, tolerance, pluralism, and mutual respect for one another. In his life, Gus Dur often set an example of heterogeneity in society and the state. For example, Gus Dur did not agree with the Indonesian Ulema Council (MUI) fatwa regarding Ahmadiyah being a sect outside Islam, heretical and misleading, and punishing its followers with apostasy (having left Islam) (Majelis Ulama Indonesia, 2005). Gus Dur is of the view that the MUI fatwa will harm the peace of the people because, during the condition of community groups who claim that their group is superior to others, the MUI's ignorance will trigger acts of violence from certain groups to other groups. . Because for Gus Dur, whatever our differences, we must live together in one bond (Basyir, 2019).

According to Miskan in his writings, he stated that the idea of multicultural Islamic education initiated by Gus Dur could be implemented in pesantren education through the example of a Kyai who loves and respects fellow human beings. Because in the life of the pesantren the attitude and behavior of the Kyai are always used as a guide in the daily life of the students (Miskan, 2018). Likewise, in the school environment, the attitude of heterogeneity can be exemplified by teachers to affect students' attitudes.

The idea of multicultural Islamic education initiated by Gus Dur is in line with the Islamic religious education curriculum issued by the Ministry of National Education, namely Islamic Religious Education is a conscious and planned effort in preparing students to recognize, understand, live, fear, and have a noble character in practising the teachings of Islam. Islam following the Qur'an and As-Sunnah (Departemen Pendidikan Nasional, 2001).

\section{CONCLUSION}

Based on the research results outlined above, the authors conclude that there are two ideas of transformative Islamic education according to Abdurrahman Wahid's thoughts, namely peace education and multicultural education. Informal education, Gus Dur's idea of peace education can be implemented through a socio-political approach by practising cooperative learning strategies, while in non-formal education, it can be implemented through dialogue and deliberation strategies. Multicultural education is the idea of Gus Dur's perspective education to give birth to heterogeneity in Indonesian society. Because according to Gus Dur, Indonesia has various ethnicities, tribes, cultures, and religions. So that the Indonesian people have the potential to experience conflict in the name of religion, ethnicity, and culture.

\section{REFERENCES}

Azra, A. (1999). Pendidikan Islam Tradisi dan Modernisasi Menuju Millenium Baru. Jakarta: Logos Wacana Ilmu.

Barton, G. (2016). Biografi Gus Dur. Yogyakarta: LKiS. 
Basyir, M. (2019). Pembelaan Gus Dur Terhadap Kesesatan Ahmadiyah. RELIGIA, 19(1), 37.

Bukhari, U. (2010). Ilmu Pendidikan Islam. Jakarta: AMZAH.

Busro, B., Mailana, A., \& Sarifudin, A. (2021). Pendidikan Islam dalam Publikasi Internasional: Analisis Bibliometrik pada Database Scopus. Edukasi Islami: Jurnal Pendidikan Islam, $10(02)$.

Departemen Pendidikan Nasional. (2001). Kurikulum Berbasis Kompetensi, Mata Pelajaran Pendidikan Agama Islam. Pusat Kurikulum Badan Penelitian dan Pengembangan Departemen Pendidikan Nasional.

Dharwis, E. K. H. (Ed.). (1998). Gus Dur (NU dan Masyarakat Sipil). Yogyakarta: LKiS.

Echols, J. M., \& Shadly, H. (1987). Kamus Inggris Indonesia. Jakarta: Gramedia.

Ghazali, A. M., \& Busro, B. (2017). Pendidikan Islam dalam Dinamika Kehidupan Beragama di Indonesia. Intizar, 23(1), 93. https://doi.org/10.19109/intizar.v23i1.1615

Halim, A., \& Adnan, A. M. (2018). Problematika Hukum dan Ideologi Islam Radikal (Studi Bom Bunuh Diri Surabaya). Ulul Albab: Jurnal Studi Dan Penelitian Hukum Islam, 2(1), 32.

Handoko, A. (2019). Analisis Kejahatan Terorisme Berkedok Agama. Salam: Jurnal Sosial Dan Budaya Syar'I, 6(2), 156.

Hori, A. A. S. M. (2020). Pemikiran Pendidikan Islam. Bandung: Cendekia Press.

Husein, M. (2021). Sang Zahid: Mengarungi Sufisme Gus Dur. Yogyakarta: LKIS.

Kasmahidayat, Y. (2010). Agama dalam Transformasi Budaya Nusantara. Bandung: Bintang Warli Artika.

Ma'ruf, M. (2020). Tipologi Pemikiran Gus Dur Tentang Pendidikan Islam. Atanwir: Jurnal Keislaman Dan Pendidikan, 11(1).

Majelis Ulama Indonesia. (2005). Fatwa MUI.

Miskan. (2018). Pemikiran Multikulturalisme KH. Abdurahman Wahid dan Implikasinya terhadap Pendidkan Agama Islam di Indonesia. Al-Furqan: Jurnal Studi Pendidikan Islam, 6(2).

Mulyadi. (2019). Pemikiran Gus Dur Tentang Pendidikan Islam Multikultural. Fikrah: Jurnal Pemikiran Dan Pendidikan Islam, 12(2).

Nurani, H., \& Nurdin, A. A. (2018). Pandangan Keagamaan Pelaku Bom Bunuh Diri di Indonesia. Jurnal of Islamic Studies and Humanities, 3(1), 81.

Nurkholis. (2013). Pendidikan Dalam Upaya Memajukan Teknologi. Jurnal Kependidikan, 1(1), 25.

Rachman, B. M. (2006). Membela Kebebasan Beragama. Jakarta: The Asia Foundation.

Ridhwan, D. S. (2018). Esensi Pendidikan Islam Dalam Perspektif KH. Abdurrahman Wahid. Istighna: Jurnal Pendidikan Dan Pemikiran Islam, 1(1).

Sa'diyah, H., \& Nurhayati, S. (2019). Pendidikan Perdamaian Perspektif Gus Dur: Kajian Filosofis Pemikiran Pendidikan Gus Dur. Tadris, Jurnal Pendidikan Islam, 14(2).

Salim, \& Sahrum. (2007). Metode Penelitian Kualitatif. Bandung: Rineka Cipta.

Sutrisno, H. (1998). Research Methodology (2nd ed.). Yogyakarta: ANDI Press.

Triani, D. A. (2016). Implementasi Strategi Pembelajaran Kooperatif (Cooperatif Learning) Tipe 
Jigsaw di Perguruan Tinggi. Universum, 1O(2), 221.

Usman, H. (2006). Social Research Methodology. Jakarta: Bumi Aksara.

Wahid, A. (1983). Amar Makruf Mabadi Kahiri Ummah dan Pancasila. Panji Masyarakat, 15(408).

Wahid, A. (1984). Saya Ingin Membalikan Arus. Panji Masyarakat, 21.

Wahid, A. (1999). Pesantren Masa Depan. Bandung: Pustaka Hidayat.

Wahid, A. (2006). Islamku, Islam Anda, Islam Kita. Jakarta: The Wahid Institute.

Wahid, A. (2017). Tuhan Tidak Perlu Dibela. Yogyakarta: LKiS. 